\title{
From Birnamwood to Bollywood: A View of the Cinematographic Adaptation of Macbeth into Maqbool
}

\author{
Rinshila Arakkal ${ }^{1}$ \\ ${ }^{1}$ M.A Student, Department of English, Farook College (Autonomous), Calicut, India
}

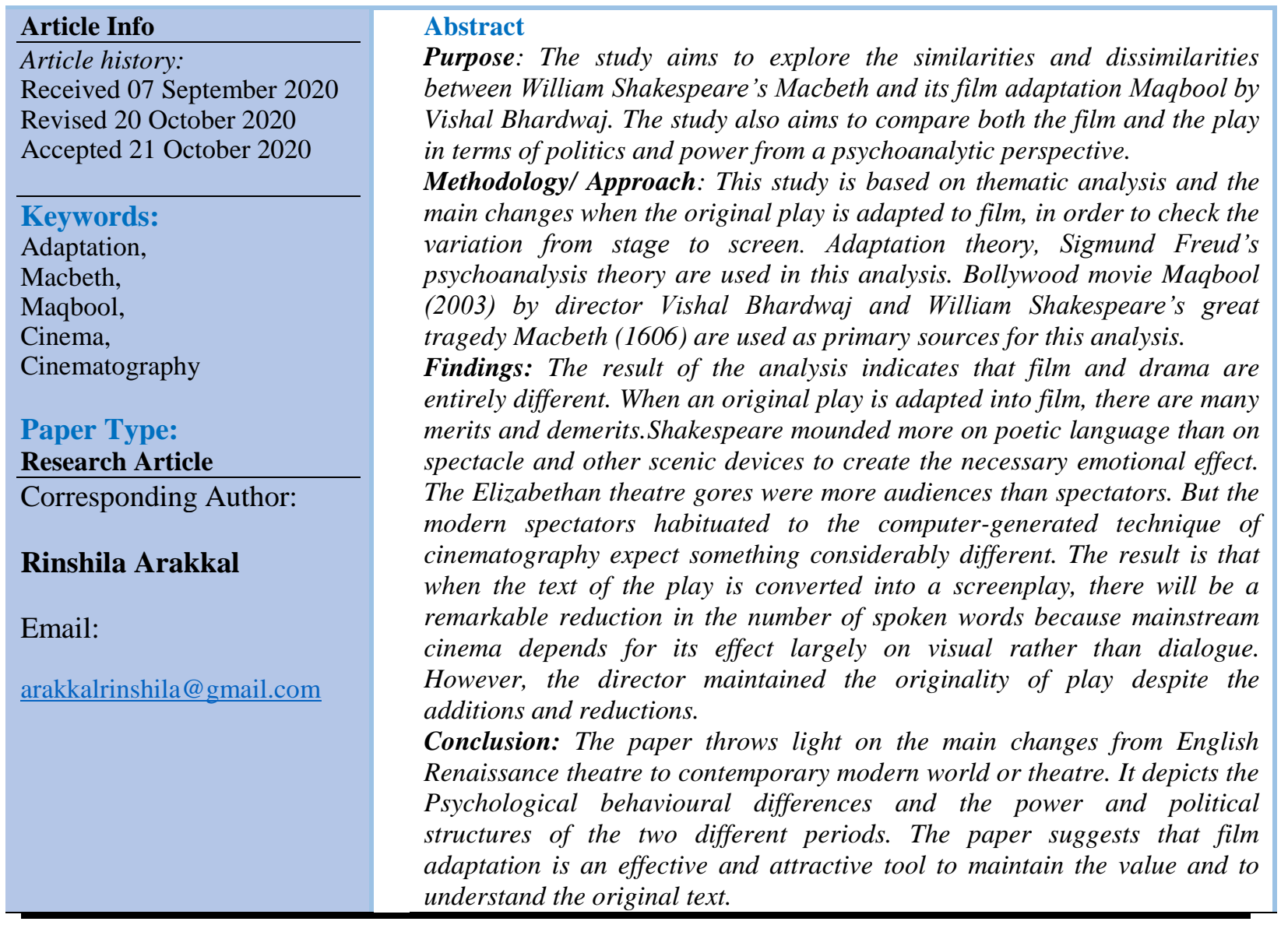

\section{Introduction}

Hindi cinema, often known as Bollywood, is recognized as the largest film producing industry in the world (Nicolaou ). It produces films in a variety of genres, like comedy, tragedy, satire, action, romantic, etc. Among these various genres, adaptation films are also seen now and then in the industry. Vishal Bhardwaj is one of the important names in that genre. Adaptations are everywhere today; on the television, internet, movie screen, musical and drama stage, in comic books and in novels etc (Cartmell 18). Adaptation is a specific process which includes the changeover of one genre to a new genre: novels and plays into films or musicals, or film adaptation is the transfer of a work or story into a feature film. In doing so, breakdown its original form and structure and add something new to make it more 
taken as a turn of modification. It undergoes through many processes such as decoration attractive and beautiful. This very molding of one genre to another generic method can be and clipping, but at the same time, it can be taken as a procedure involving addition, expansion, insertion, and accumulation of many things.

Shakespeare remains a consistently popular choice for film makers throughout a century of cinema. America, France and Britain made over 200 film versions from Shakespeare's works. The plays are clearly rich texts and very suitable for film makers to produce good films. The plays are never indented to be read by a wide audience they are mainly written as texts for performance in a theatre. Interestingly, film introduced an entirely new way of presenting the plays to new audience, with films as a distinct form in its own right and with its own language. The process of film adaptation is normally based on written screenplay, to some extent, on the basis of its original text. The faithfulness of the screenplay to the text can vary immensely, with some film makers are taking out characters and restructuring the order of the text and cutting the whole scenes. To make the screenplay to life, the film makers will also need to decide on cinematic elements that will demonstrate how they want the film to look and feel, and how they will convey the action and themes to the audience.

Shakespeare tragedies have been a perennial source of inspiration for all filmmakers across the world. While some attempt transpose the text exactly and recreate the period on screen, others like Vishal Bharadwaj have their own mixing and matching. There are many feature-lengths film and TV versions of William Shakespeare's plays as having been produced, making Shakespeare the most filmed author ever in any language. The practices of displacing the settings is commonly applied to Shakespeare's plays both on stage and screen in order to create the effect of poetry Shakespeare movies are so numerous; they form their own sub-genre. With over 250 Shakespeare film adaptations such as BazLuhrman's "Romeo and Juliet", the Shakespeare inspired "Shakespeare in Love" and the more recent "Hamlet 2000", prove that Shakespeare films adaptations and movies retain their enduring appeal. As an example of Shakespeare's enduring popularity, sixty one film adaptations and twenty one TV adaptations alone have been made of Hamlet, the earliest being in 1907 and the latest in 2000. As Shakespeare's best-known and most adored text, certainly one of the world's most read text Macbeth has driven numerous artists and writers across the globe. Bollywood has some successful adaptations of Shakespeare's plays to its credit. The universality of Shakespeare's plays, being read, taught, staged, enacted and adapted to other forms of art even today is unquestioned as his characters expressed emotions that would equally appeal to Elizabethan audience as well as contemporary readers. The fact that Maqbool is a classic of Indian cinema and can be admired by anyone irrespective of its connection with the play is also true.

\section{Methodology/Approach}

This research article discusses the process of cinematographic adaptation of Macbeth into Maqbool (2003), a film directed by Vishal Bhardwaj who is particularly known for his love for the Bard, having made a trilogy on his plays. Maqbool is an adaptation of 
Shakespeare's classic play Macbeth. It was released in 2003 and located in the grey area between art house and mainstream cinemas. Sigmund Freud's psychoanalysis theory is used here to discuss the similarity and differences with regard to the sleepwalking scene, to compare psychological approach of Lady Macbeth, Nimmi, Macbeth and Maqbool towards their bloody murder of King Duncan in drama and Jahangir Khan in Maqbool. The discussion also extends to cover politics and power in Macbeth and Maqbool. In Macbeth Shakespeare compares the political accounts of Holinshed and Maqbool is not a complete political film but it depicts the power that underworld has over politics and Bollywood. It presentsa detailed analysis of Macbeth and Maqbool, a close reading of drama and the film highlighting the similarities and dissimilarities.

\section{Analysis and Results}

Geoffrey Wagner (1975) divided film adaptation into three 'modes': a) the transposition, in which a work of literature is directly given on screen with a minimum of apparent interference, b) the commentary, where an original story is taken and either purposely or inadvertently altered in some respect and c) the analogy, which must represent a considerable departure for the sake of making another work of art. Maqbool seems to be belonging to the second 'mode'. That is, the commentary, as the movie shows some degree of deviation from the play to suit Indian sensibility and cater to the taste of this audience. Maqbool is an adaptation of Shakespeare's classic play Macbeth, was released in 2003 and located in the grey area between art house and mainstream cinema, Maqbool is a dark, fascinating transcription of emotion, sexuality, lust for power madness and personal enmities. Maqbool on the other hand is set in the backdrop of Mumbai underworld with a Mafia Jahangir Khan replacing the king of Scotland Duncan and Maqbool playing his right hand, instead of a General in the army. Maqbool remains a close confidante of Jahangir initially. The witch sisters are replaced by the corrupt inspectors in the film. It was the astrological prediction of the inspectors that lead Maqbool to believe that he could one day take over Jahangir Khan, the shift from Scottish aristocracy to underworld mafia. Shakespearean tragedies have a perpetual source of creativeness for all filmmakers across the world, while some attempt transpose the text exactly and reconstruct the periods on screen, others like Vishal Bharadwaj have their own ways of mixing and matching. And starring PankajKapoor, Irrfan Khan, Tabu ,MasumehMakhija, Om puri, Nasrudeen Shah, Piyush Mishra, AnkurVikal etc.

Nimmi is shown as a mistress to Abbaji and a secret beloved of Macbeth (and not Maqbool's wife) probably because Indian audience likes to watch a romance rather than see it culminate in marriage and look at the characters as spouses instead of sensational lovers. Some characters are shown less dynamic than they are in the play and vice versa. Also, in the movie, a surreal atmosphere is created by showing the characters' allegiance to Islam and their using of heavy Urdu at some places probably to make it go well with the setting of the Mumbai under world and the characters to look realistic as gangsters. Then, the addition of Sameera ( Abbaji's daughter whom we don't find in Macbeth ) and Guddu romance works 
well in creating a solid difference between Maqbool and Macbeth. So, all these differences make Maqbool fall into the "second mode" of film adaptation, as mentioned earlier.

\section{Sigmund Freud's Psychoanalysis theory on Macbeth and Maqbool:}

Psychoanalytical criticism or Sigmund Freud's psychoanalytical theories often applied to literature in order to understand deeply about characterization, motivation, and influences and examines the manifestation of issues which arise from a person's subconscious. According to Lois Tyson, In Critical Theory Today, Freud believed that "the notion that human beings are motivated, even driven, by desires, fears, needs, and conflicts of which they are unaware." Based upon this, one could easily apply the psychoanalytical analysis on Shakespeare's Macbeth and Vishal Bhardwaj Maqbool. Both in film and in text the characters like Macbeth, Lady Macbeth, Nimmi and Maqbool are touching with id, ego and super ego. The influences of Psychoanalytical theory of Sigmund Freud can be trace very deeply through the character Lady Macbeth, in Act 5, scene 1; she displays the significances of the unconscious mind.

Psychoanalysis theory concentrates on the conscious and unconscious mind of human beings. Freud was one of the most prominent theorists of the twentieth century and his stable legacy has not only influenced by psychology, but art, literature, and even the way of people bring up their children. He discovered the human mind rather than any theorist who came before him. Freud considered id, Ego and Super ego are three important aspects that develop a person's mind or personality. This invention happened in 1856-1939, and this theory or therapy commonly used treat disorders, anxieties, depressions etc. He described and examined very deeply and concentrated on this theory rather than any other experts in this field. Sigmund Freud also expanded the definition of sexuality and major components of personality; he defined the importance of unconscious.

The play Macbeth seems to be characterized by the transfer of 'psychic forces' from one person to another. Initially, Lady Macbeth's thoughts are initially representative of id, personifying the "illness that should tended" (1.5.18) the ambition of murdering king Duncan, while Macbeth is far more taken by the superego, with such thoughts repressed and substituted with a sense of morality ("He's her in double trust"(1.7.12)). However, in dialogue with his wife, Macbeth voices only more tangible reality based assessments of the situation (the loss of "golden opinions" (1.7.34)) rather than these ethical objections (which arose in solitude), clearly indicating the presence of the ego as a moderating dialectic force.

Lady Macbeth is fairly ambitious and moderately sexual. She wished to be a queen and put a heir on the throne. It is due to some complexities in her mind or as a compensation for childlessness. She tried to redefine her own and her husband's sexual roles. Like the Witches with their manly beards, with a confusing sexual identity, Lady Macbeth also unsexes herself. Similarly with her bloody deeds and actions Macbeth attain power by killing the king Duncan. Lady Macbeth is a lonely woman in this play and she is individually different from other female characters of Shakespeare, she has no companion, and other female characters to support her, even though she has no children and her lonely journeys are depicting through it. She dedicated her life to her husband and they want achieve their dreams and her life 
completely concentrates on Macbeth's life. She need society, power, rather than her husband, she is his dearest companion of Macbeth. She tells her thoughts and feeling to Macbeth alone. Her loneliness leads her self-centredness, daydreaming and state near madness, as revealed by her reaction to Macbeth's letter.

From a psychoanalysis methodology, Lady Macbeth's superego is overriding the id, Ego. Similarly, Lady Macbeth's sleep walking Scene can connect with her mental illnesses and as her psychological syndromes. Lady Macbeth, in her somnambulism, appears to go through the dreadfulness of the horrific murders that she has tempted Macbeth to commit. Lady Macbeth says that hell is dark. Then she looks to reverse the life-tape to those days when Macbeth has broken into a sweat of fearing at the very idea of Murdering Duncan. In sleepy condition she says that no one can question them and they are free doing anything, any authority not bothered about them. Actually her inner thoughts and feelings are showing through this, her distracted mind, her fear is depicted here. And she is saying that all the perfumes of Arabia will not enough to cleanse her hands. Lady Macbeth's hand stills the smell of King Duncan's blood.

Lady Macbeth: [Her hands to her noses] The smell of the blood is still there. All the perfumes of Arabia cannot sweeten this little hands. [She sigh deeply] Oh, oh, oh!

Doctor: "What a sigh that was! Her heart is heavy-burdened." (Act 5, Scene 1) (Shakespeare, 59)

From the conversation between Lady Macbeth and doctor gives an idea of Lady Macbeth's mind, her troubled self, due to King Duncan's murder. Still King Duncan's murder haunts her and she is in mad condition due to that horrible crime. Lady Macbeth has been able to retain her sense of guilt under control when awake, but in her sleep it gets the better of her. She stimulated her husband to do that bloody deeds and after the murder, their hands were coloured in Duncan's blood, she set out to wash them clean. In her somnambulism state she feels that the stain of blood is still on her hand and the smell of blood cannot wash with all perfumes of Arabia. Lady Macbeth troubled by the smell of blood, while Macbeth haunted its colour, that bloody red colour haunted him a lot. "The little hand" specifies that she has been an elegant, gentle person. This word flashes back her earlier dialogues that a little water is enough to wash all deeds. "A little water clears us of this deed: How easy is it then".(2.2.64) This was her statement soon after the murder of king Duncan, this indicates what she was and what she is, her dialogues in her sleep walking scene reveals her the haunted images of crime and she itself reveals the tragedy of her personality. For Lady Macbeth, the murder of Duncan is as dismissible as simply running a little water over one's hands to rinse them off. Later in this play, Lady Macbeth's unknown, to her, conflict abruptly rises to the surface. She is seen sleepwalking and trying to rub a "spot" of her hand.

Out, damned spot! Out, I say (5.1.35) 
Here, her unconscious (the superego) has overpowered her conscious (the id, the ego). Even the doctor, who has been sent to examine her, find that,

Doctor: "This disease is beyond my practice: yet I have known those which have walked in their sleep who have died holily in their beds." (Act5, Scene 1) (Shakespeare, 59)

Lady Macbeth herself reveals the all the secrets of crime, that she has committed. Evidences are very clear from her somnambulism state. Her sense of guilt which she has been able to keep under control has the sense of guiltiness which she has been capable to keep under control, has the whip- hand of her mind in her sleep. And not keep any secrets of Queen Lady Macbeth's disease. It is outside the possibility of his medical proficiency, for it has its origin from in moral, not psychical disorder. Peoples walk in sleep that can cure with help of medical skills and abilities with more medical advancement. In case of Lady Macbeth it is difficult, she has no physical complaints but she as problems related to her psyche or mental disorder. As a queen she gets all facilitated medical treatments and with the help of expert in the medical field. But her problems cannot cure by any doctors because, she has no complains related to her physical organs, her disorder is related to mental conditions.

Then Shakespeare differentiates between somnambulism caused by nervous imbalances and that caused by psychological disorder.

Doctor: Foul whisp'rings are aborded: unnatural deeds

D breed unnatural troubles: infected minds

To their deaf pillows will discharge their secret:

More needs she the dive than the physician:

(Act 5, Scene 1)

(Shakespeare, 60)

Doctor watched and observed Lady Macbeth's characteristics and her illogical utterances during somnambulism, and doctor understands that Lady Macbeth needs a priest rather than a physician. Her troubles are showing her sense of guilt. The doctor expresses to Lady Macbeth's that unnatural deeds do have unnatural results on those who commit them. Guilty men are always confesses their secrets in sleep, similarly Lady Macbeth has confessed a lot in her somnambulism state. She needs a priest to unburden herself from all the deeds. The doctor has hit the nail on head, for the absence of a priest or a confidante to whom she could lay her heart bare, and finally Lady Macbeth commits suicide. "Unnatural deeds. Do breed unnatural trouble; infected minds", doctor denotes the guilty conscience as the diseased mind. Moreover Lady Macbeth's consciousness of doing wrong has stimulated her superego's morality.

Lady Macbeth hallucinate and understands a blood spot on her hand, this visual phantasm reveals her mental volatility in her temporal lobe, which is in authority for her visual and auditory response. But her visual hallucination may also be interconnected to mental disorder such as schizophrenia. Sleepwalking can notice in schizophrenic patients that are due to over stress and tensions. And her visual hallucinations and sleepwalking scene may 
classifies her as a schizophrenic patient. Lady Macbeth's nonstop effort to wash away the imagery of blood is associated to her emotional state of sorrow and mental instabilities.

In the end, it is suppressed behaviour of Lady Macbeth which comes to the surface to reek havoc on her life and lead to her death. Only the application of psychoanalytical analysis takes into consideration the subconscious of a character and, therefore, can be an appropriate lens with which examine the character of Lady Macbeth. Sigmund Freud's psychoanalysis theory can connect with Shakespeare's Macbeth. Shakespeare consents Lady Macbeth to obtain these provinces through the play. Id is portrayed with her desire to power. Lady Macbeth has done everything to attain royalty, and kingdom but that pushes her to become a great criminal. As a result, her ego is a significances of her conduct and in her activities, her all performances and her approaches is also the result of her ego. Through sleepwalking scene her reality is shown and the guilt that she felt. Her unconscious mind is enlightening her control of impulse, Besides Lady Macbeth's superego or conscience is depicted through her actions or all her activities and performance as the result of her superego, as it starts to claim superiority her desire or id.

Lady Macbeth: Since his majesty went to war, I have seen her rise from her bed, throw on a night-gown, unlock her strong -box, take out a paper, fold it, write upon it, read it, then seal it, and return to bed again. And all this while fast asleep. (Act 5, Scene 1)(Shakespeare, 59). This scene exemplifies Lady Macbeth's psychological state and she is unconscious and revealing her on inner thoughts of murder. Here demonstrates the importance of unconscious mind, her unconscious thoughts reveals her feelings and inner guilt. Furthermore, the psychoanalytical theory is apparent in act 5, scene1, through Lady Macbeth as the remarkably expresses the three provinces in Sigmund Freud's critical theory.

Maqbool is the eternal bleak tragedy of Macbeth set in Mumbai underworld, it is very beautiful to imagine medieval Scottish highland as a present- day Mumbai Street. Director Vishal Bhardwaj takes the real credit for this exceptionally dark underworld tale. Bhardwaj makes important changes to Shakespeare's original plot, particularly in the character configuration. There are many differences between film and play, but cannot reject the film completely because director do his well. The most drastic changes that Vishal made from the original play lie in the configuration of his female characters, since he turns the witches into men and adds more women to film. However, the biggest change lies in Lady Macbeth, who is not married to the protagonist but is Duncan's mistress.

In the film Maqbool, there are many elements that correspond to Freud's psychoanalysis theory but there are also some problems and prospects from the original text. Nimmi is the main actress and represents Lady Macbeth through this film. But Nimmi is not the real wife of Maqbool, she is mistress of Abbaji. She falls in love with Maqbool that can be traced in many scenes. During a dinner at Abbaji's home, he starts choking and Maqbool runs to the kitchen for water. When Abbaji faced difficulty when he takes food, Nimmi hesitates to give water. it is now revealed that the woman who had called Maqbool earlier in fact Nimmi ( Lady Macbeth), Abbajji's mistress, who hold on to Maqbool even though he threatens to slap her in fear of being caught. Instead she is playing with Maqbool; she was not ready give water to Abbaji. Even though Maqbool becomes too angry with Nimmi, because he loses his don and Maqbool was the right hand of Abbaji. Nimmi walking toward a shrine 
with Maqbool, actually she makes herself this change by cheating Abbaji, Maqbool also follow her as a guard to his don's mistress. Nimmi walks in barefoot and she intentionally pricks her foot on a thorn so that Maqbool can nurse her, Nimmi always wished his presence and his comforts to her. Nimmi's blood mixed with her emotions in the lyric "pairon mein padigar dishaursar mein junumbhihai" (with misfortune under my feet, my head is red-hot with madness). Finally Maqbool fall in love with and they decided to kill Abbaji, as Macbeth and Lady Macbeth. Nimmi dreams about a life as Lady Macbeth, her id here and her desires and needs to full her dreams. Even though they make love, between Nimmi and Maqbool, but the grief-stricken tune floats over their lithe bodies like a curse. Maqbool reveals the lust of power and passion as Mian Mqbool, a Muslim Mafia lieutenant and right hand of Abbaji the don in the Mumbai city. Finally he too fall in love Nimmi, they cannot separate. Their relationship was beyond the limitations. Nimmi, who also loves Maqbool and sticks him to grab the godfather's place in the hierarchy of the gang, Mian too decided to take over the power and freedom. And his wishes and dreams were the throne of Mumbai underworld. Abbaji was a hindrance and obstacle to achieve their dreams and desires. So they decided to kill him.

Nimmi: That every day should pass...Just like tonight (55:33)

Nimmi said they cannot live together with happiness and power with the presence of Abbaji, every day should pass just like this. So they want to kill Abbaji to reach the royalty. Similarly, they believed that Abbaji's presence break their relationship, they want genuine relationship rather than illegitimate relationship.

Nimmi: Not possible whilst believes (55:39)

Nimmi: And afterAbbaji is gone. (55:45)

So, Nimmi's approach towards Abbaji is clear from the visual depictions, her id is working here and her desire for power and ambitions are very clear. As Lady Macbeth does Nimmi too motivates and attempts Mian Maqbool to achieve their destiny. Nimmi's inspirations and encouragements helped Maqbool to do the bloody deeds and crime against his role model and his don Abbaji. This id is spontaneous and unconscious, Nimmi became unconscious due to mad love towards Mian Maqbool, that is part of Nimmi's psyche which responds directly or indirectly, and it helped Nimmi and Mian Maqbool immediately to basic urges, needs and helped to fulfil her desires. So they Killed Abbaji to achieve their desires and needs. The Id functions on the pleasure principle which is the idea that every ambitious and hopeful impulse should be satisfied immediately, irrespective of consequences. When the Id achieves its demands, experiences a kind of pleasure. When Id is denied a kind of unpleased feeling or tension will create. It is fact that both Maqbool and Nimmi enjoyed a kind pleasure. Id engages in primary process thinking, which is primitive, inconsistent, and fantasy oriented. It is absolutely right in the case of Nimmi, her illogical, fantasy oriented thoughts make Maqbool as great criminal in the Mumbai underworld kingdom. The ego is progressing to mediate between the unrealistic id and the external real world, it is the decision making factor of personality. Preferably, the ego works by reason, whereas the id is confused 
and bad-tempered. Like id,ego also search for pleasure in order to reduce the tension in mind. So Nimmi and Mian Maqbool make love in order to reduce tension and Nimmi became pregnant, their love making also helped to forget Abbaji.The ego engages in secondary process of thinking, which is rational, realistic and oriented toward problem solving. Nimmi tries to cover many things from Sameera, and Nimmi's acting is very evident from last scenes where she sits near to Abbaji's dead's dead body in order to reject suspicions from her.

According to Rosa M. Garcia- Peragio says of Nimmi in her comparison with the popular film actress- "Although Nimmi is not precisely the image of virtue per se for she is portrayed as a prostitute, her love for Maqbool prevents her from being a plain carnal figure to Abbajii" (Dionnee 69). From funeral prayer of Abbaji itself, the ego works on Nimmi, her guilt is evident from that scene. Maqbool prays for Abbaji and said that Abbaji may rest in peace. From that Nimmi's ego is clear when she sees dead body of Kakka her approach and her reactions indicates her ego. Nimmi called Mian very loudly due to her fear and the guilt always haunts her.

\section{Nimmi: Miyaan (loudly) (1:15:13)}

Similarly the ego works on Maqbool, when he saw Kakka's dead body ,when Mian look at Kakka's dead body to expresses his grief and to break all suspicions from other peoples, suddenly Kakka's dead body open his eyes and stare at him. It was a great shock for Mian as Macbeth watches the Banquo's ghost from banquet scene. Superego aims for perfection; it is a kind of thought of as a type of conscience that punishes misbehaviour with feelings of guilt, for example, for having extra- marital affairs. The super ego controls our sense of right and wrong and guilt. Nimmi's super ego works here, that is very evident from her bedroom scene. The blood mark on her face that troubles her and she tries to wash of that blood stains. She looking again and again to the mirror but it is still on her face. Maqbool was afraid of the scenes that also work on him as a super ego. From Shakespeare's Macbeth, this scene is very evident and Lady Macbeth says that all perfumes of Arabia will not enough to cleanse her bloody deeds.

\section{Maqbool : "kyahuva" (what happen) (1:25:27)}

Maqbool asks to Nimmi about her present situation due to her sadness and guilt, this is also an example for super ego. Now Nimmi hunts the guilt of murder of her former husband. Maqbool comfort her with confidence, but he too hunts the guilt of his right hand Abbaji. And Maqbool slaps on her face and tried to make her confident, otherwise the secret behind their crime will reveal and that may destroy their life and hard work behind their murder. Nimmi was in an insane stage in hospital after giving birth to a child. That may due to her inner conflicts and guilt that also gives that the idea or concept Sigmund Freud's super ego in psycho analysis.

Doctor :"yeehkyakerraha"? (1:32:33)

Don't you know she is serious? $(1: 32: 34)$

Yeh what are you up to $(1: 32: 37)$ 
Nimmi is so serious as lady Macbeth in schizophrenic situation, here the lady doctor advices Maqbool that don't take her from critical condition, and she is serious, perhaps she may lost her life. Nimmi is like paralyzed and it is due to her inner feelings and guilt. This is also similar to Lady Macbeth and her similar situation in sleepwalking scene. Actually she is in unconscious condition and Maqbool feels Abbaji's presents, he is dancing with other members. These scenes are like hunting images that may due to his fluid mind as the result of the bloody deeds. In bed room Nimmi running here and there and washing and rubbing the wall as Lady Macbeth continuously wash her hands to remove the blood stains. Her insanity approaches is great example for super ego. Their intensive is cry significant of their guilt and regret.

\section{Politics and Power in Macbeth and in Maqbool}

Throughout the history, literature has been used to express certain view points on different governments. During William Shakespeare's time, monarchy is the dominating form of government. Although writing plays can be a dangerous business, especially when reflecting on the position of the king, William Shakespeare is able to write Macbeth without upset too many critics, and certainly not the Queen of England. William Shakespeare writes Macbeth as a political analysis focusing solely on the position of the king, the divine right of Duncan, the tyranny of Macbeth, and finally the restoration of peace and nature in Malcolm.

Shakespeare's inspiration for Macbeth comes from Holinshed's Chronicle, 1577, but his reason for writing the play when he did was very likely political. The political play Macbeth, which tells the story of Macbeth, a Scottish general once he met a trio of witches and they predict that he will become the king of Scotland. And this play shows the inter relationship between prestigious royal court and the rural life. This play is set likely that a certain monarch, by the name of King James 1 was a model for Shakespeare. James 1 was a patron of the arts and was very keen on Shakespeare and his work. It would be prudent to keep the king happy and so Shakespeare's treatment of Macbeth shows good, wise, blessed king like Duncan and king Edward of England who are meant to reflect King James's own divine qualities, but sometimes Shakespeare's way of saying that King James should step down the throne. Macbeth himself represents the evil conspirators who would dare to commit treason and regicide, resulting in a sticky end. The play therefore stands as a cautionary tale for anyone else who might be considering doing away with the current monarch. This play explores the difference between good kingship and bad kingship and also says about what are the things that make a king good, also focuses on how a king becomes poor ruler. Shakespeare also depends on Holinshed's "chronicle of England, Scotland Ireland" or his historical plays. Macbeth is a play based on an episode in the history of Scotland. The murder of Duncan is based on Holinshed's account of the murder of king Duff by Donwald. Donwald is instigated by his ambitious wife to the crime and his servants put the king's servants to sleep with drugs when the king is a guest in his house. Donwald kills them without giving them a chance to prove their innocents. 
A nation enjoying serenity, harmony and wealth ruled by a flawless monarch, generous, mild and strong... that was Scotland under King Duncan. But his splendid supremacy came to a dishonourable end when he was murdered by none other than his most favourite friend, Macbeth, Thane of Glamis. God himself, Duncan's power is given from the almighty God himself, so there is no way anyone should dispute Duncan's power. Although, Duncan is assassinated and removed from the play, as the play continues, Shakespeare still gives glimpses of the divine right theory. A powerful judging against the king by the join forces of the Vikings and the Thane of Cawor was quelled and the rebels wiped out by the royal army under Macbeth. The happy grateful king decided to confer the title and the land of the executed Thane of Cawor on Macbeth send this messenger to convey the good news to Macbeth.

The play Macbeth is considered to be a political play and blended with some evil elements that cause this play into tragedy. Macbeth's lust for power is an important factor that leads to a great tragedy by the intervention of some evil protagonists, like Macbeth, Lady Macbeth and the troubled influences of that trio witches. Macbeth was a loyal, honourable, kind general in Scotland with the title the Thane of Glamis, but that loyalty lead to his destruction. Macbeth blindly followed the prophecies of three evil spirits, that prediction maintained lust for power and supremacy with Macbeth. If the lust for power entered in politician's mind they do anything to achieve it, even they will ready kill their opponents. Political murders are still happening to achieve their kingships. Here Macbeth's lustful ambition for power and to become a king leads him to kill King Duncan. Macbeth was King Duncan's right- hand, trustworthy friend.

\section{Duncan: My worthy Cawdor! (Act 1, Scene 4) (Shakespeare, 11)}

So the first prophecy of those trio evil sisters became true, first prophecy fulfilled.... It had come to Macbeth without asking to him. The well-educated politicians blindly believe in such super natural spirits and priests. That may be due to their over lust for power. They do everything in a secret manner. Shakespeare confusingly suggest that the three main characters contribute many things actually they are politically contributed to this great tragedy, Lady Macbeth, Macbeth and three witches makes this play as tragedy. Lady Macbeth forced Macbeth to the immoral paths so cannot be a good King. Lady Macbeth influenced a lot and encouraged him to achieve power

Lady Macbeth: what monster was it then that made you share this scheme with me? When you dared to do it, then you were a man. To have ambition is to be so much more than man. Before, neither the time nor the place was right- yet you were. (Act1, Scene 7)

Lady Macbeth repeated Macbeth that by having hidden the desire of becoming the king, he had already taken the first steps of murder. She blamed him for his cowardice...the hero in war, the courageous husband don not have the confidence to take the first step of murder or no courageous to take the first step that may lead him to the throne. His pride was hurt to the quick, but Macbeth still stood in the ground. He assured that he will do all things that a man 
dares to do in order to prove his courageous in front of his wife. Macbeth was still uncertain of success. As for his wife, a failure had no place in her life so decided to do anything for her and their power. It is very clear that every murder should have provoke, so people greatly influenced by a background team or their dedication to someone. Here Lady Macbeth influences him and exploiting his courage to attain power. She advised him to screw up his courage to the sticking point and they could not fail. Even though Macbeth always waking with fearful shoulders, terrible that been betrayed by someone who suspects the truth. Macbeth becomes more and more of an oppressor; Macbeth tried to put his deeds on other's head that causes bloodshed in Scotland.

But the former king Duncan was very loyal to his kingdom all peoples were happy with that royal kingdom of Duncan. Duncan's majestic appearance coupled with his meek and gentle nature wins the heart of all. Macbeth dwells heartbreakingly on his goodness, even though the cruel Lady Macbeth too wretched toward him, she laments that Duncan is like her father while she slept. Duncan has not given any slenderest provocation to Macbeth to commit the crime. Just like him, some politicians may cover all hearts, some social workers and freedom fighters too etc. We are very proud of an independent nation that may be other's hard work. So King Duncan was a role model of that majestic kingdom, enjoying prosperity and peace. At that time the evil minded Macbeth decided to achieve power. But the demerit of King Duncan is that his powerlessness to judge the men, that is seen from beginning to still his death. The throne of Scotland was then not hereditary, still he announces his son Malcolm his successor. It was an injudicious step, especially when Macbeth had concentrated such unforgettable services to the country.

Malcolm was Macbeth's great enemy, because he was the son of King Duncan and the successor to the throne. He remains and figured as a shadowy figure in the beginning of the play, but Malcolm became strong after the death of his father, his judiciousness and caution are seen after the murder of his beloved father. He detects the unfelt sorrow in Macbeth's lamentation and resolve upon immediate flight. Every politicians has own family for support, if they were in trouble their family will support them. In case of Malcolm his father's murder cannot afford to him. His diplomatic skill makes him suggest that his army should use Birnamwood as a camouflage. Malcolm in the play represents the good king. He is honest and he has not given much attention for his passions and lust, he is not that much ambitious like Macbeth. And he gives courtesy for the needs of his people first. Another good king in England's Edward, whose virtue allowed to heal the sick. In Macbeth Shakespeare makes an attempt to give more importance for country and its citizens for their prosperity. All these qualities and to make a kingdom with prosperity Shakespeare tried to give moral virtue of its king. Scotland's power structure and political intrigue is clearly depicted through this play. Actually murder of the king Duncan is an activity or Macbeth's aim is to gain political power. Subsequent murders Macbeth to achieve political power and maintain kingship. And he does many crimes to achieve the political power and he wants to remain the king of Scotland. Macbeth defeated through a political alliance between those who in Scotland who wish to bring him down. But finally Macbeth became in trouble and isolated. His great supporter lady Macbeth committed suicide. His back born of all his decision has gone. And Macbeth also troubled with suspicions and guilt. Again Macbeth approached that bloody 
sisters for his confidence. This is very relevant in modern world because all educated peoples still approaches the superstitious believes in order to attain a kind of consolation. But Macbeth's still believes that his power and position is safe, no one can reject his power and throne. But the weird sister's predictions have some twist, but Macbeth believes that he is safe until the Birnam wood comes to the royal palace. But it was a contradictory statement or prophecy in itself has his future.

Macbeth: I have almost forgotten the taste of fears:

The time has been, my senses would have cooled

To hear a night- shriek, and my fell of hair

Would at a dismal treatise rouse and stir

As life were isn't: I have supped full with horrors;

Direness, familiar to my slaughterous thoughts,

Cannot once start me. (Act 5, Scene 5) (Shakespeare, 66)

Macbeth was very confident and he has almost forgotten the taste of fear. There was a time when screaming in the night would have Macbeth turned cold. Macbeth jam-packed with horrors, ghastly sounds and sights are commonplace in Macbeth's murderous thoughts. But now Macbeth is brave and confident because of his power and position. It is clear that if a person gets position and power he will forgot all fears and horrors. And that position lead to people achieves more and more, their determination should be gain power by break downing all the obstacles that shackles them. Similarly, Macbeth is too confident without fearing his future. He is like a successor gained all power. Macbeth used political tactics to achieve the attention of Scotland citizen and he wished to a king like King Duncan. Finally Macbeth surrounded by his enemies and with no mean of escape before him. Macduff renter the scene and Macbeth advised him to leave, because his mind is already disturbed his family's death. But Macduff replay with sword and fights. And finally all manliness shattered from Macbeth. And Birnam woods have marches to palace and finally the corrupt King understand his own death, and also recognize no prophets or witches can help him. Finally Macduff carrying Macbeth's head on his hand, he greets Malcolm as a new King to Scotland. Malcolm, now the King in Scotland and freedom returned to the country. Now the country became free from the evil hands and peoples are happy and welcomed the new King.

All histories and literature focused on their government and politics one a certain point of view. Writing a play about politics was a dangerous thing and it may affect author when he portrayed the kingdom or political situation in a bad manner, so authors always focused on good aspects of their governments, especially when reflecting the position of king .But used good methods without upsetting any one. In Macbeth Shakespeare used and depicted the King Duncan in a good manner, proclaimed about his generosity king, and majesty. William Shakespeare penned Macbeth as a political analysis or from a political point of view, solely on the position of King, the marvellous right of Duncan, the dictatorship of Macbeth, and finally the rebuilding of peace by new King Malcolm. The play begins with the murder of King Duncan, instantaneously this position dared through an invasion from Norway. Shakespeare used this scene to portray the situation of Scotland and demonstration 
the divine theory of monarchy. Duncan gets the power from the almighty god, so one asked about his power. Suddenly or from the beginning of the play itself Duncan assassinated and removed from the scene. Macbeth was ambitious and he was in confusion, is it good or bad the murder of King Duncan, because King Duncan was a divine being. Lady Macbeth's sleepwalking scene or her death due the murder of this divine person. Similarly if a good politician or king died that affect that country and all their zones. If finishing that Macbeth was strictly written about King James 1, this was Shakespeare's way of representing King James 1 and this way he should step down the throne. Macbeth said that he has no friends, no honour and no love, these are essential things that need for a good king. So it is clear that he is not a good King But Shakespeare could have also been inferring that the King James was a weak King. From these description gives an idea that at that time, honourable Kings were a rarity. From the beginning it analysed many elements of insanity, the death of Duncan starts with the madness and continues it until the end of play. So there are many elements of insanities in the world of Macbeth, it is like or same as in England at that time. The world is shifting from positive elements to negative elements, like war, death, evil. That evil spirit leads Macbeth to murder someone and he misunderstands that may help him to achieve power and throne. This natural world is not a fictional world in Macbeth but it depicts also $17^{\text {th }}$ century.

In film Maqbool, Vishal Bhardwaj takes the kingdom of Scotland as underworld of Mumbai. Here Abbaji the powerful don in Mumbai, he represents King Duncan who killed by his adopted son, his right hand Maqbool and Nimmi. Actually the film Maqbool not really depicts the politics or it cannot be consider as a political film but it depicts the power the underworld has over politics and Bollywood. Director focuses on Bollywood because at that time when the film released many wanted gangsters were threatening and blackmailing many loyalists of the Hindi film industry. Another reference in film Maqbool where Abbaji is given a money-spinning and beneficial offer to become a partner in drug business, that may help him to achieve the attention of world and ensures his presence all over the world. Abbaji expresses his deep love toward Mumbai and he was the King as Duncan and he was not ready leave that Mumbai, and not ready to settle in Karachi or in Dubai, because Mumbai is his sweet heart.

Abbajii: "Mumbai hamari mehboobahai, Miyan.

Issechhodkar hum Karachi ya Dubai me nahi bass saktehai." (40:03)

This is a suggestive of Dawood Ibrahim, he is an important Mumbai underworld figure and most demanded criminal. He is too supposed to have an enormous business empire in Dubai and in Karachi. Indian government offered Millions and Millions for his head, because he was a strange drug dealer and criminal gangster. He entitled the most dangerous underworld don in Asia itself. Perhaps he may have a great support from laws and powers. In the film there are many elements that trace the great influences of Inspectors and other political leaders, who helped Abbajii and Maqbool to gain the power.

In film, Maqbool uses gun without any fear, even though Maqbool and his gangs entered to home and killed the victims in front of their family members. A child cries very 
loudly and calls his father "Aboo ... Aboou..." (papa.. papa..) (6: 49/ 1:48: 47). And Guddu says that leave from there to that boy in front of a bloody murder.

Guddu: "Get lost" (7:11)

Guddu: "Take the blasted kid outside" (7:19)

From this scene we can trace the power and violence of Mumbai gangsters; they directly entered to the house of criminals or victim and kill them without any kind or compromise. Here in Chotti's house gangsters entered to and decided to kill, even though a little boy cries loudly for his father and other family members too stunned in front of this horrible scene. All power and positions gained by gangsters and demonstrated a fraudulent democracy in order to make or create wrong idea among people. Peoples have not got much attention from government, power and politics influenced by money rather than opinions from peoples. All power and structures based on money, even though they not need an election or democratic system. Abbaji holds the power in Mumbai under world and kill mercilessly the criminals and his gangs too decide the future of Mumbai. The rulers in politics and in power, they blindly follow the laws and orders from the don and his assistances, not even consider whether it is right or wrong. Two inspectors Purohit and Pandit involved actively in chit chat of Mumbai underworld and try to implement according to the wishes of don that may help them to achieve a good profit or effect on their ranks and positions. Dons are controlling the whole world rather than the laws and orders. Devsare an important police officer called these inspectors to inform his arrival, but they were in a jolly mood and their excessive amount of liquor made them unconscious, replied to Devsare very badly.

Pundit: Hello... who Devsare?

Call at the station in the morning.... (11:00)

Purohit: Who in the world is this Devsare?

Maqbool: Your new ACP

This is very clear that the gangsters well known about the new appointments in their city rather than the co-workers. Here the arrival of new ACP is unknown for the policemen but Maqbool knows this news very quickly. So the influences of gangsters and their political power are very evident from this scene.

Devsare: Where were you two at the time of the crime? (12:09)

Devsare shows his doubt on these inspectors and they said that they were on duty at that time of duty.

Purohit: The balance of power is critical in this city, (12:19)

Devsare enquired the condition of city and inspectors said that the city is under the control of Abbaji, even though inspectors to show their gratitude towards Abbaji. Because they hesitate reveal his original name and addressed the don as only Abbaji, from this itself Devsare understand the intimacy and the relationship between Abbaji and them. 
Devsare: What's his name?

Inspectors: The father (Abbajii) (12:36)

Devsare: I want his name not your relationship. (12:39)

Police inspector explains about Abbajji and revealed his original name that is Jahangir Khan. Laljibhai's commander- in- chief at one time, and he started off his operations smuggling gold and after Lalji's death, took over all the contacts killings and land mafia operations. The messiah... of the minorities, whichever party he backs never loses at the elections. Devsare understood that he has arrested once... twelve years ago and attempted to attest him only resulted in riots all over the city. From these Devsare understands the image Mumbai's don and his power in the city. All citizens are blindly living with a fear and troubles in Mumbai city. Abbaji was in great revenge to those who killed his brother and he is seeking for the murder. Asif finally killed by Abbaji as a burden of his brother's death. Similarly, after their dinner they are taking the numbers of murder and his friend said that three of our men killed in this week. From this gives as idea about assassinated peoples, that is a usual case in their history and this shared by prominent politicians from Mumbai city. So the political intervention is very clear and powered politicians make all facilities for gangsters, they both of them maintain a good relationship. But Devsaree is a dutiful police and he cannot afford with the dons domination in Mumbai city, and he questioned Abbajji and Maqbool tried to prevent Devsare from questioning his right hand. Dutiful policemen Devsare reacted to Maqbool and slap on his face. Devsaree gets his punishment transfer from Abbaji and the gangsters mockingly said that they may miss him and always god may bless him. Once Police station was a guest house for Abbaji but Devasree mistreated and punished him. Many leaders and polices tried to protects criminals and crimes at the same time there are many trustworthy or dutiful policemen they usually protect the common peoples and their laws. And finally Maqbool too obsessed with the position and power and he decided to kill his right hand and the don Jahangir Khan. After the death Abbajii Maqbool and Nimmi decided to take that position but that troubled them. The ghost images and Nimmi became insane due to the guilt. The power and harmony cannot enjoy this greedy couples and finally both Nimmi and Maqbool fall into a great pit as result of their ambition for power.

There are many political elements in this film, the don Abbajii was obsessed with the Mumbai city and he refused to go anywhere out of this city and it can be considered as a way to differentiate himself from other Muslim criminals known for their anti-India activities. And this film represented the Muslims in a bad angle. Muslim gagster's refuse ignominiously in petty vendettas, extortion, alcohol, and illicit sex, Hindu authority overcomes the mean sin of mortality through cooperation with the transcendent forces of existence. The intracommunal violence of the movie, by which Muslims kills Muslims, is inter-communal after all, but insidiously so, as it has been instigated and nourished by the Hindu authorities (Pandit and Purohit) so that its bearing is only inward, toward a small, blind Muslim community at the centre of the story from an arc inscribed and veiled by the Hindu establishment.

Shakespeare's writing reflects his thoughts and beliefs on society and politics. Play Macbeth distinguish between good kinship and bad kingship through King Duncan and King Macbeth. At the end of the play the entire plot change into insanity, the death of King 
Duncan starts this madness and it continues till the end. Shakespeare wanted to make the point clear that while all of this insanity is happening in the world of Macbeth, it was happening at the same time in England. Hawkes states, "Macbeth witnesses a birth: we are in at the death" (Greenhaven press 50) this quote infers that Shakespeare sees a relapse in the natural world. The world is shifting from a positive one to death, war, and evil rule. Evil in the way that even he will pursue murdering someone if it means he will take over the throne. This natural world is not only the fictional world of Macbeth, but also $17^{\text {th }}$ century England. The themes of spirituality, witchcraft, evil and supernatural in Macbeth, Shakespeare could have used this work to tip his hat acknowledges the evil and dark inside of the reigning Scottish king. Similarly King Duncan's murder seems to not have much motivation, but it does follow historical accuracy. In the article Political ideas in Macbeth, Lily B.Cambell explores the Act4, Scene 3 in Macbeth and correlates it to King James. The first is the testing of Macduff; the second is the account of the healing of the king's evil and third is the news of killing Macduff's wife and children. All these accounts are identical to Holinshed's writings to a point; the fact that he included these episodes proved that Shakespeare gathered multiple examples of regicide from Holinshed to create Macbeth.

Political elements are less in the film Maqbool by Vishal Bhardwaj. So it focused in Mumbai underworld than political conflicts. So there are many problems when a play adapted to film, if, directed show and depicted power the Mumbai underworld has over politics and in Bollywood. When this film was released the wanted gangsters were blackmailing film stars and the whole film industry. This film set among gangsters and powerful overlords. Both film and play are two levels of power and position in political background.

Literary adaptations gave cinema the respectable cachet of entertainment-as-art. Each film is the site of a cultural, artistic and personal negotiation the counters of which may be mapped by careful analysis of visual figuration and imaginary. Because Shakespeare's play were intended to be performed on the bare platform stage of the English Renaissance Theatre, each director must invent a visual design to accompany or supplant the play text. And precisely because words and images, plays and films are so different, study of Visual style can often reveal the implicit terms on which Shakespeare and contemporary directors meet. There is a general consensus that the power of a Shakespeare play resides in the language employed, may be because of the restrictive Elizabethan stage conditions.

Shakespeare banked more on poetic language than on spectacle and other scenic devices to create the necessary emotional effect. The Elizabethan theatre gores were more audiences than spectators. But the modern spectators accustomed to the computer-generated technique of cinematography expect something drastically different. The result is that when the text of the play is converted into a screenplay, there will be a tremendous reduction in the number of spoken words because mainstream cinema depends for its effect largely on visual rather than dialogue. A screen play is a story told in picture, and not picture.

A cinematic discourse differs from that of a novel or a play, for it tells the story through image and sound. Discourses also refer to the social process of making sense and reproducing reality, and thereby of fixing meanings. Apart from strong and active characters, a stylized visual narrative is necessary for the story to move forward. Films depend mostly on non-verbal means of communication. In spite of the difference between Elizabethan 
dramaturgy and modern cinematography Shakespearean texts have proved to be highly successful in film translations too. The cinema can match the fluidity of action on the Shakespearean stage better than the modern theatre. Since the Elizabethan stage had no drop curtain, one scene moved on to the next and all scenes formed a continuous sequence, more like the modern cinema than the modern drama. It is because of this sequential order of scenes in Shakespearean that the film versions of his texts have found a prominent place in the international market unrestricted by consideration of language and untroubled by the relatively archaic dialogue of the originals. Like the films of other 'classics', they confer respectability on their markers and distributors. The brand name of Shakespeare is a sure guarantee of its success. The impact of Shakespeare in contemporary film industry has been such that movies based on Shakespeare's works are regarded as forming a distinct genre.

In a way, the question of "fidelity" comes down to making the adaptation a work which is as powerful as the literary work itself. And Maqbool undoubtedly measures up to the criterion that makes it a powerful work. It is a standard in its own right in the world of adaptations. Brilliant performances by actors, simple yet impressive settings and awe inspiring direction makes it an exceptional work of art, winning wide acclaim from critics and analysts alike. There are undoubtedly problems in adaptations and as long as popular and canonical literary works will be adapted to screens, the problem of "destroying the sanctity" of the literary work will continue to haunt us. There is no doubt that adaptations cannot match the merit of the original literary work but one possible solution to the problem could be looking at both the text and adapted version independent of each other, as separate works / pieces of art or one just as an inspiration from the other and not really comparing the two. Somdutta Mandal quotes Joy Gould Boyun saying, "In assessing an adaptation, we are never really comparing book with film, but an interpretation with an interpretation. For just as we are readers, so implicitly is the filmmaker offering us, through his work, his perception, his visions, his particular insight into his source. An adaptation is always, whatever else it may be, an interpretation." Henry James's assertion that art lives upon discussion, upon experiment, upon curiosity, upon the exchange of views and the comparison of standpoints also ably sums up the debate.

\section{Conclusion}

Literary adaptation to film is a long established tradition in cinema staring, for example, with early cinema adaptations of the Bible. By the 1970s, adaptations of the established literary canon had become a marketing ploy by which producers and exhibitors could legitimize cinema going as a venue of 'taste' and thus attract the middle classes to their theatres.The similarities between the play and film are quite evident, the characters and scenes such as the famous opening scene with witches and their predictions, banquet scene, Maqbool and Nimmi's illusions and hallucinations etc clearly hint at the original Macbeth in some way or the other. Also making Nimmi (equivalent to Lady Macbeth) Abbaji's mistress sufficiently increases her wicked and manipulative nature. She is menacing and seductive, but keeps an innocent look on her face, making herself even viler. The way she delivers her taunts is perfect. The depiction Of her insanity is heart wrenching. Bhardwaj accords Nimmi 
much of the plot's twists and turns, she uses her sexual control over Maqbool, plants the seed of murder in his head, uses all her wits to cast her spell over him and Abbaji. She does justice to Lady Macbeth's character, her madness and guilt consciousness near the climax of the movie is parallel to lady Macbeth's sickness in act 5, sc I. She keeps wiping her face for she thinks there's blood on it still, her cleaning the wall as she sees blood all over it reminds one of the scene when Lady Macbeth says " here's the smell of blood still; all the perfumes of Arabia will not sweeten this little hand. Oh oh oh".

There are many differences between film and play, Nimmi is publicized as a mistress to Abbaji and not Maqbool's wife, because audience like to romance than marital relationship. Some characters are shown less dynamic than they are in the play and vice versa. Witches are replaced by two policemen, inspector Pandit and Purohit are in the employ of Abbaji. For them future is tangible as present. Bhardwaj probably wished to highlight the link between corrupt police and uderworld, making them the 'witches' of the present day. Then the addition of Sameera and Guddu romance works well in creating a solid difference between Macbeth and Maqbool. There are undeniably problems in adaptations and as long popular and canonical literary works will be adapted to screen. The problems of Originality or purity of the literary work will destroy. There is no doubt that adaptations cannot match the merit of original text, so to overcome this problem could be looking up on both the text and adapted version independent of each other, as separate works or piece of art.

\section{Conflict of Interest}

None

Funding

None

\section{Work Cited}

Bambhaniya, Girish. Macbeth to Maqbool: Vishal Bhardwaj's cinematic adaptation of Shakespeare's Macbeth. Institute of Language Teaching ,Rajkot, 2019.

Cartmell, Deborah, ed. A companion to literature, film, and adaptation. John Wiley \& Sons, 2012.

Clemishire, Kash. Shakespeare on politics in Macbeth.okstateshakespeare, Oklahoma state university.2014.

Jha, Noopur, and Arunabh Banerjee. "William Shakespeare's Macbeth to Vishal Bharadwaj's Maqbool: A case study on adaptations in contemporary Indian Cinema." International Journal of English Language, Literature and Humanities 4.7 (2016): 303-312. https://doi.org/10.1080/25723618.2020.1844932

Maitra, Sritama, and Sangeeta Mukherjee. "Indian decentrings of Macbeth: postmodern creativity in filmic adaptations by Vishal Bhardwaj and Jayaraj." Creativity Studies 13.2 (2020): 585-599. https://doi.org/10.3846/cs.2020.12787

Maqbool.Dir. Vishal Bhardwaj. Per. Irfan Khan, Tabu and PankajKapoor, Kaleidoscope Entertainment, 2004.Film. 
Nicolaou, Elena. What Makes Bollywood Movies So Special. 6 Oct. 2020, www.oprahmag.com/entertainment/a33396048/what-is-bollywood/

Pratibha. Shakespeare on screen: A view of the cinematographic adaptation of Macbeth into Maqbool. Veda's Journals of English Language and Literature, vol.4, no. 4.2017, pp. 12-34.

Rahman, Rezwana. Bollywood's representation of Shakespeare, a postmodern Study: Macbeth-Maqbool, Othello-Omkara, Hamlet-Haider. Diss. BRAC University, 2017.

Rodgers, A., Bhardwaj, V., \& Bhardwaj, V. (2016). Vishal Bhardwaj [Review of Maqbool; Omkara; Haider]. Shakespeare Bulletin, 34(3), 500-504. https://www.jstor.org/stable/26355203

Sacheva, Pankaj. The political elements in Vishal Bhardwaj's cinema. 2019. Dichotomy-ofirony.blogspot.com.

Sander, Julie. Adaptation and Appropriation. New York: Rutledge Publication, 2006. Print. Shakespeare, William, Macbeth, Rodger Barton,1606.

Singh, Saurabh Kr. "Adaptation and Appropriation: Macbeth into Maqbool." An International Refereed e-Journal of Literary Explorations 2: 760-764.

Thomas, Kartin.The Land of Macbeth.Shakespeare Institue.

Ghosh, Anuradha. "Poonam Trivedi and Paromita Chakravarti, eds. Shakespeare and Indian Cinemas: â€ œLocal Habitationsâ€." Asiatic: IIUM Journal of English Language and Literature 13.1 (2019): 171-174. 